\title{
FORUM
}

Submitted 04·30.2013. Approved 08.26.2013

Evaluated by double blind review. Scientific Editors: Wesley Mendes-Da-Silva, Newton C. A. da Costa Jr, Lucas Ayres,

Manuel Rocha Armada and Jill M. Norvilitis

DOI: http://dx.doi.org/10.1590/So034-759020150104

\section{DISPOSITION EFFECT AMONG BRAZILIAN EQUITY FUND MANAGERS}

\author{
Efeito disposição entre gestores brasileiros de fundos de ações \\ Efecto disposición entre gestores brasileños de fondos de acciones
}

\begin{abstract}
The disposition effect predicts that investors tend to sell winning stocks too soon and ride losing stocks too long. Despite the wide range of research evidence about this issue, the reasons that lead investors to act this way are still subject to much controversy between rational and behavioral explanations. In this article, the main goal was to test two competing behavioral motivations to justify the disposition effect: prospect theory and mean reversion bias. To achieve it, an analysis of monthly transactions for a sample of 51 Brazilian equity funds from 2002 to 2008 was conducted and regression models with qualitative dependent variables were estimated in order to set the probability of a manager to realize a capital gain or loss as a function of the stock return. The results brought evidence that prospect theory seems to guide the decision-making process of the managers, but the hypothesis that the disposition effect is due to mean reversion bias could not be confirmed.
\end{abstract}

KEYWORDS | Loss aversion, disposition effect, prospect theory, mean reversion, logistic regression.

\section{RESUMO}

O efeito disposição prevê que os investidores tendem a vender ações ganhadoras muito cedo e fazer uso de estoques de perda por muito tempo. Apesar da grande variedade de evidências de pesquisas sobre o assunto, os motivos que levam os investidores a agir dessa maneira são, ainda, objeto de muita controvérsia, havendo explicações racionais e comportamentais. Neste artigo, o objetivo principal foi testar duas motivações comportamentais concorrentes para justificar o efeito disposição: a teoria prospectiva e o viés de regressão à média. Para tal, foi realizada uma análise de transações mensais com uma amostra de 51 fundos brasileiros de capital, de 2002 a 2008, sendo que foram estimados modelos de regressão com variáveis dependentes qualitativas a fim de se definir a probabilidade de um gestor vir a ter ganho ou perda de capital em função do retorno de ações. Os resultados trouxeram evidências de que a teoria prospectiva parece guiar o processo dos gestores de tomada de decisão, mas a hipótese de o efeito disposição se dar devido à diferença para o viés de regressão à média não pôde ser confirmada.

EDUARDO POZZI LUCCHESI eduardo.lucchesi@fecap.br Professor at Centro Universitário Fundação Escola de Comércio Álvares Penteado - São Paulo - SP, Brasil.

\section{CLAUDIA EMIKO YOSHINAGA}

claudia.yoshinaga@fgv.br Professor at Centro Universitário

Fundação Escola de Comércio

Álvares Penteado - São Paulo - SP, Brasil.

FRANCISCO HENRIQUE FIGUEIREDO DE CASTRO JUNIOR

hcastro@usp.br

Professor at Universidade de São

Paulo, Faculdade de Economia,

Administração e Contabilidade - São

Paulo - SP, Brasil.
PALAVRAS-CHAVE / Aversão à perda, efeito disposição, teoria prospectiva, regressão à média, regressão logística.

\section{RESUMEN}

El efecto disposición prevé que los inversores tiendan a vender acciones ganadoras muy pronto y a hacer uso de stocks de pérdida durante mucho tiempo. A pesar de la gran variedad de pruebas de investigaciones sobre el tema, los motivos que llevan a los inversores a actuar de esta manera son, todavía, objeto de mucha controversia, existiendo explicaciones racionales y de comportamiento. En el presente artículo, el objetivo principal fue el de comprobar dos motivaciones de comportamiento concurrentes, para justificar el efecto disposición: la teoría prospectiva y la tendencia a la reversión a la media. Para ello, se realizó un análisis de transacciones mensual, en una muestra de 51 fondos brasileños de capital, de 2002 a 2008, en que se consideraron modelos de regresión, con variables dependientes cualitativas, con el fin de definir la probabilidad de que un gestor tenga una ganancia o pérdida de capital, en función de la rentabilidad de las acciones. Los resultados arrojaron pruebas de que la teoría prospectiva parece guiar el proceso de toma de decisión de los gestores, pero la hipótesis de que el efecto disposición se produce debido a la diferencia a favor de la tendencia a la reversión a la media no pudo confirmarse.

PALABRAS CLAVE I Aversión a la pérdida, efecto disposición, teoría prospectiva, reversión a la media, regresión logística. 


\section{INTRODUCTION}

One of the main postulates of the traditional finance theoretical framework is that economic agents evaluate their decisions under conditions of uncertainty in accordance with the expected utility theory, which is based on axioms that describe a rational choice and have been widely accepted as a descriptive model of economic behavior.

Over the last three decades, a series of experiments (Kahneman \& Tversky, 1972, 1973, 1979; Tversky \& Kahneman, 1973, 1974, 1986) showed that economic agents exhibit preference patterns incompatible with the expected utility theory. One of the main alternative approaches to the expected utility theory is the prospect theory of Kahneman and Tversky (1979), which is a description of the way people take decisions under risk.

According to this approach, investors structure their choices in terms of potential gains/losses relative to a fixed point of reference, and then employ an S-shaped evaluation function, which is concave in the gain region and convex in the loss region. This reflects risk aversion in the domain of gains and risk propensity in the domain of losses. This reasoning implies that an important phenomenon is at play here: people's response to losses is more extreme than their response to gains, i.e., the annoyance associated with the loss of a sum of money is generally greater than the pleasure associated with a gain of the same amount. This phenomenon became known in literature as loss aversion.

Based on the finding that decisions under conditions of risk are influenced by loss aversion, Shefrin and Statman (1985) saw how these ideas could be applied to the financial market and tried to determine if investors are reluctant to realize losses. The authors developed a positive theory of capital gains and losses, in which investors tend to sell stocks when they are showing a profit (winning stocks) in a short period of time and to keep stocks that are showing a loss (losing stocks) for longer time. They named this bias as disposition effect. Some studies tried to document the disposition effect based on different datasets and periods of time and found that this cognitive bias is seen both in individual as well as in institutional investors. However, despite the wide range of studies that detected the disposition effect, the discussion about the causes that lead investors to manifest this bias still persists.

According to Odean (1998), the evidence that supports the hypothesis that investors sell winning stocks more quickly than losing stocks is generally unable to explain the reasons to it. Some authors allege that there is a rational motivation for the disposition effect while others argue that the motivation is behavioral. Among the arguments used by the first group, three are worth highlighting: (i) investors may respond to a large price increase in one stock by selling some of the shares of that stock to restore the diversification of their portfolios" (Lakonishok \& Smidt, 1986); (ii) investors who bought some stocks based on favorable information may sell them if the price rises, rationally believing that the price now reflects this information, and may continue holding the stock even if the price falls, rationally believing that the information has still not been incorporated in the price (Lakonishok \& Smidt, 1986); and (iii) transaction costs tend to be greater for depreciated shares and, considering that it is more likely that losing investments are depreciated in comparison with winning investments, investors may decide not to sell losing stocks simply to avoid the high transaction costs involved (Harris, 1988).

Despite these rational motivations, Odean (1998) argues that the causes of the disposition effect are more aligned with behavioral arguments, since the results of his study showed that, even when all the previously listed rational motivations are controlled, investors still manifest the disposition effect.

Among the arguments that allege behavioral motivations for explaining the disposition effect, the first one predicts that investors have a value function as the prospect theory claims. The second one is related to the fact that investors incorrectly expect that there will be a mean reversion in the stocks returns. An incorrect interpretation of mean reversion is a judgment bias that occurs when individuals fail to correctly reflect about the propensity that certain events have for tending toward the mean. Regardless of the argument used, whether rational or behavioral, the existence of the disposition effect means that investors (individuals or institutions) will not get the optimal returns.

On the one hand, Brown, Chappel, Silva Rosa and Walter (2006) state that disposition effect implies significant economic costs, such as the inability to take advantage of tax benefits on unrealized losses. On the other hand, Odean (1998) and Locke and Mann (2000) argue that the disposition effect also compromises investment performance.

In a survey conducted in the American market, Odean (1998) showed that winning stocks that are sold give an abnormal mean return $3.4 \%$ greater than that of losing stocks held for a subsequent period of twelve months. This result provides evidence that investors who tend to sell winning stocks too early and ride losing stocks too long are, on average, mistaken.

Locke and Mann (2000) in a study based on transactions by professional futures contracts' traders concluded that the success of the operations was negatively correlated with the degree of loss aversion. Such findings justify the reasoning of Shefrin (2005) that there are some reasons to suspect that disposition effect has some influence on stock prices. 
Another important aspect is the fact that the proponents of the expected utility theory argue that the behavior of individual investors is becoming less relevant as financial markets are increasingly being dominated by institutional investors and that these professionals are more prone to presenting a rational behavior since they are better informed than individual investors and enjoy the most efficient analytical tools available (Shapira $\&$ Venezia, 2001). The above argument raises an important question about the immunity of professional managers to behavioral biases. For Shapira and Venezia (2001), such immunity is justified by the influence of the training and experience of these managers, who are less expected to present judgment bias.

Considering the supposed immunity of professional managers to behavioral biases and based on the fact that the empirical evidence that supports the disposition effect is generally not able to explain the behavioral motivations that lead investors to act in this way, this study attempts to respond the following research questions: (1) Do Brazilian equity fund managers exhibit the disposition effect? (2) The disposition effect arises because fund managers have value functions like those described in prospect theory or because they incorrectly expect mean-reverting prices?

\section{DISPOSITION EFFECT}

The disposition effect is a behavioral bias based on the notion that investors manifest a reluctance to realize losses. It was originally studied by Shefrin and Statman (1985) within a theoretical framework that includes four important elements: prospect theory, mental accounting, regret aversion, and self-control. In addition to that, Odean (1998) included a fifth element, which is the mean reversion bias.

\section{Prospect theory}

The disposition effect is a direct implication of the prospect theory of Kahneman and Tversky (1979) for financial markets. According to this, decision makers structure their choices in terms of potential gains/losses relative to a fixed reference point. Then they use an S-shaped evaluation function, which is concave for gains and convex for losses. This reflects risk aversion in the gain region and risk-seeking in the loss region.

Weber and Camerer (1998) illustrate this reasoning with the following example: suppose an investor buys a stock for price $P$ and that in the subsequent period, the stock loses an amount $L$ in value, for a price $P$ - $L$ (this stock is called loser stock). In this case the investor may sell the stock or keep it. If he keeps the stock there is an equal probability of the stock returning to its purchase price $P$ or falling once more by the amount $L$, to a price $P-L-L=P-2 L$. In the inverse situation, the stock gains in value by $G$ to a price, $P+G$. If the investor keeps the stock there is an equal probability of the stock falling to the price $P$ or rising by the amount $G$ to a price $P+2 G$.

Figure 1 shows what happens when the investor's reference point is the original purchase price of the stock $(P)$. In this case, the losing stock is worth $P$ - $L$ if it is sold, and $P$ or $P-2 L$ if kept. If the investor's reference point is the original purchase price of the stock $(P)$ the investor will structure his investment decision as a choice between a certain loss with a negative value $v(-L)$, or keeping the stock and accepting a game with the value $v(0)$ (break-even point) or $v(-2 L)$. If the investor is risk-seeking in the loss domain (and the probability of reaching break-even point or once again losing the amount $L$ is equal), he will keep the stock. Weber and Camerer (1998, p. 170) state that "investors will keep losers because the pain of a further loss $L$ is less than the pleasure of recovering the purchase price".

\section{Figure 1. Prospect theory and the disposition effect}

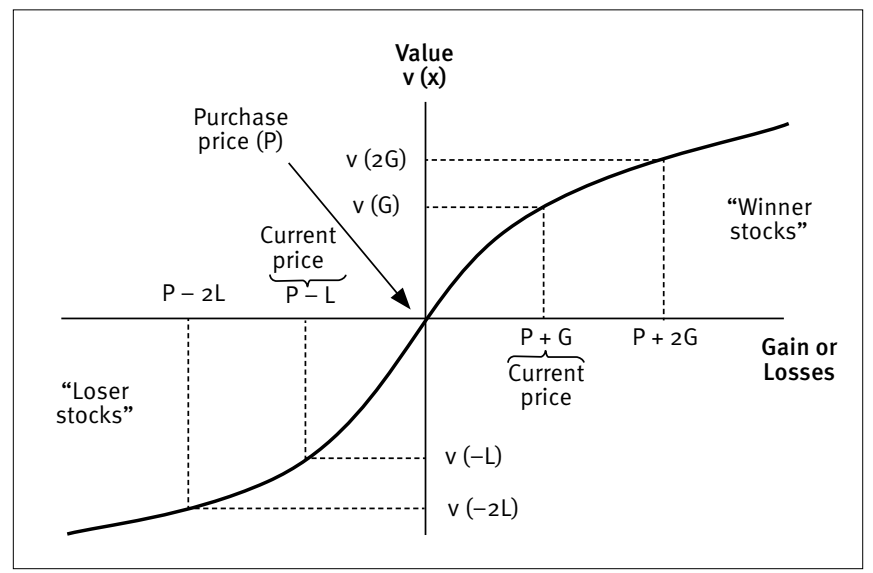

Source: Weber and Camerer, 1998, p. 170.

In the case of the winning stock, its value is $P+G$ if it is sold, and $P$ or $P+2 G$ if kept. If the investor is risk averse in the gain domain, he will sell the stock to have a certain gain $(G)$, thus creating a gain with a value $v(G)$ instead of accepting a game with a value $v(2 G)$ or $v(0)$. In this case, the investor will sell the winning stock because the pleasure of an additional gain for an amount $G$ is less than the pain of seeing the price of the stock return to price $P$.

One important aspect highlighted by Odean (1998) is that testing the disposition effect implies testing a joint hypothesis that assumes that both the model predicted by the prospect theory and the specification of the reference point chosen by the investor are correct. 


\section{Mental accounting}

Discussion of the prospect theory emphasizes the importance of the structuring phase of the choice and the definition of the reference point. To supply a basis on which decision makers structure choices, Thaler (1985) formulated a structure known as mental accounting. The central idea is that decision makers tend to segregate different types of choice into separate accounts and, therefore, apply decision rules based on the prospect theory for each account, ignoring any possible interactions.

Application of this concept to equity investing establishes that when a stock is bought a new mental account is opened and if the investor specifies his reference point as being the original purchase price, a running score is maintained in this account indicating gains or losses with regard to the purchase price.

\section{Regret aversion}

The third element that contributes towards explaining the disposition effect is regret aversion. Shefrin (2002, p. 10) considers that "regret is the emotion experienced for not having made the right decision". Therefore, regret is more than the pain of the loss; it is the pain associated with the feeling of having been responsible for the loss. Along the same line, Shefrin and Statman (1985) state that investors may resist realizing losses because such an attitude is a proof that their assessment was wrong. In this case investors would show more reluctance to realize losses because they would have to admit their own mistakes.

Shefrin and Statman (1985) also state that the positive counterpart of regret is pride. While closing a trade position with a loss induces regret, closing it with a gain leads to a feeling of pride. Therefore, the search for pride and aversion to regret (regret is stronger) leads to inaction being favored over action. Consequently, investors prone to this bias may be reluctant to realize both gains and losses.

\section{Self-control}

The fourth element of disposition effect theoretical framework is the problem of self-control, presented by Thaler and Shefrin (1981) as an intrapersonal agency conflict between an individual's rational side (principal) and emotional side (agent). This conflict can be understood in a similar way to the agency conflict between the owners and managers of a company.

Thaler and Shefrin (1981, p. 392) state that "both individuals and firms use the same techniques to mitigate the problems which the conflicts create". One of the most common techniques used by investors to minimize their reluctance to realize losses is the stop loss order. These orders are generally promoted as an ef- fective way of managing risk, but their main advantage consists in allowing the investor to realize his losses at an automatically pre-determined point. In this way, transforming loss realization into an automatic procedure works as an effective tool for minimizing the influence of the investor's emotional side.

\section{Mean reversion}

Finally, the last element that helps to explain the disposition effect is the mean reversion bias which arises from the representativeness heuristic.

Representativeness implies that consistency in the sequence of past performance causes investors to place a firm into a category, and forms predictably biased expectations about future performance. The pricing implication of representativeness is that investors might over-extrapolate past performance and thus set prices too high or too low, which generates return reversals in future (Chan, Frankel, \& Kothari, p. 9).

This effect, known as the overreaction effect suggests two important hypotheses: (1) extreme movements in stock prices will be followed by movements in the opposite direction, and (2) the more extreme the initial price movement the greater will be the subsequent adjustment.

According to Odean (1998) investors may choose to hold on to their losing stocks and sell their winning ones, not because they are reluctant to realize their losses, but because they believe that today's losers will shortly outperform today's winners. However, the author argues that if the expected return on the losing stock is greater than that on the winning stock the investor's belief would be rational and justifiable. Nonetheless, if the expected return of the losing stock is not bigger than the expected return of the winning stock but the investors continue to believe that it is despite persistent evidence, then this belief is irrational and therefore unjustifiable.

\section{EMPIRICAL EVIDENCE}

Since the seminal work of Shefrin and Statman (1985), the disposition effect became object of a large number of studies in many countries. The evidence available on the subject can be divided into two groups: (i) those that tried to investigate the disposition effect based on analysis of purchase and sale transactions made both by individual investors and by professional managers, and (ii) those that tried to identify the presence of the disposition effect by carrying out experiments. 
In the first group, among the studies that tried to report the disposition effect in individual investors, those that stand out are Odean (1998), Ranguelova (2001), Dhar and Zhu (2002) and Ben-David and Hirshleifer (2012) on the American market and Boebel and Taylor (2000) and Brown et al., (2006) on the New Zealand and Australian markets, respectively. The evidence that tried to identify the disposition effect among professional managers includes the studies by Locke and Mann (2000) and Frazzini (2006) on the American market and by Tizziani (2008) on the Brazilian market.

Some authors tried to report the presence of disposition effect both in individual investors and in professional managers. Shefrin and Statman (1985) studied the American market, Grinblatt and Keloharju (2000), the Finnish market, Shapira and Venezia (2001), the Israeli market, Karsten (2005), the Brazilian market and Barber, Lee, Liu and Odean (2007), the Taiwanese market. Experimental studies, which form the second group, were conducted by Weber and Camerer (1998) in Germany, and by Macedo (2003), Mineto (2005) and Arruda (2006) in Brazil.

Finally, some authors tried to build models in order to understand and predict the disposition effect. This is the case of Barberis and Xiong (2012) that build a general equilibrium model to examine the implications of prospect theory for the disposition effect and Li and Yang (2013) that presented a model of realization utility in order to predict the disposition effect.

It is important to emphasize that, from the Brazilian perspective, this study uses a similar database like that used by Karsten (2005) and Tizziani (2008). In both cases, to identify the disposition effect, the authors used tests for difference in proportions to check if the proportion of gains realized by investment fund managers exceeded the proportion of realized losses. Unlike the approach of Karsten (2005) and Tizziani (2008), the purpose in this paper is not to establish a positive (and statistically significant) difference between the proportion of realized gains and the proportion of realized losses by investment fund managers. The main goal of this study is to check if the probability of an equity fund manager selling a particular stock is positively related to its return using a qualitative-dependent variable regression model.

\section{RESEARCH METHODOLOGY}

\section{Sample selection and data collection}

To investigate the disposition effect in Brazilian professional managers, a sample of equity investment funds ranked by the $\mathrm{Na}$ tional Association of Investment Banks (ANBIMA) as Ibovespa Active Equity Funds was selected. According to the definition on AN-
BIMA's website these funds use the Bovespa Index (Ibovespa) as their benchmark. Furthermore, at least two thirds of the portfolio must be invested in stocks, subscription bonus or subscription receipts, stock deposit certificates, stock funds quotas, stock index fund quotas and Brazilian Depositary Receipts (BDR) classified as Level II and III, with or without leverage.

A sample of 120 funds was selected according to the above criteria, based on a list of Ibovespa Active Equity Funds, as published by Valor Econômico (Brazil's most influential financial newspaper) on page $C_{5}$ on January 5,2009 . The next step consisted in checking the availability of the monthly composition of these portfolios on the Brazilian SEC's (Comissão de Valores Mobiliários - CVM) website. CVM Instruction 302/99, article 64 , obliges the fund managers to disclose the composition of their portfolios on a monthly basis. However, managers have a maximum period of ninety (90) days after the end of the month to disclose this information, as published in CVM Instruction 409/04, article 68.

Until 2002, information about the composition of fund portfolios was sent in paper form. Since July 2002, it has been sent to the CVM electronically and thus it became available on its website. Since the data were collected between January and April 2009, depending on the year when the funds were constituted, it was possible to obtain their prior historical data between July 2002 and June 2008.

After checking the availability of the fund portfolios in the sample selected, two measures were taken. The first was to exclude Equity Fund Quotas because such funds do not invest directly in stocks, but in quotas of other investment funds. After these first criteria, 35 funds were excluded. The second measure consisted in excluding the funds whose data series were incomplete, which led to a further 34 funds being excluded.

For each of the funds in the sample the following data relative to the composition of the funds were collected every month from the CVM's website: name and code of the stock; quantity and value of realized sales in the month; quantity and value of realized purchases in the month; final position (covering quantity, cost, and market value) and the weights invested in each stock. The data were then reorganized with the purpose of classifying the assets in alphabetical and chronological order.

For analysis purposes, only those stocks or stock receipts (such as UNITS and BDRs) were maintained in the fund portfolios. The other assets in the portfolio that did not fit these categories were excluded. After selecting the fund sample and collecting the data referring to the composition of the portfolios two logit regressions are proposed in order to verify if the disposition effect arises because fund managers have value functions such as those described in prospect theory. 


\section{Binary logit model}

The main purpose of the binary logit model is to verify if the stock return is positively correlated to the probability of the stock being sold, controlling for the fund size. The model presented below is an alternative approach since most empirical evidence about disposition effect is supported by tests for difference in proportions.

$$
E\left[Y=1 \mid X_{i, f, t}\right]=\frac{\exp \left(\beta_{0}+\beta_{l} \text { Re } \operatorname{turn}_{i, f, t}+\beta_{2} 1 \mathrm{n} N A V_{f, t}\right)}{1+\exp \left(\beta_{0}+\beta_{l} \operatorname{Re} \operatorname{turn}_{i, f, t}+\beta_{2} 1 \mathrm{n} N A V_{f, t}\right)}
$$

The dependent variable $\left(Y_{i, f, t}\right)$ represents two possible alternatives that can occur in month $t$ : the manager of fund $f$ can either sell stock $i\left(Y_{i, f, t}=1\right)$ or hold it $\left(Y i_{, f, t}=0\right)$. Equation (1) is estimated for two different models: in model 1 , Return ${ }_{i, f, t}$ is defined as the stock continuous return $\left(C R_{i, f, t}\right)$, and in model 2 as the market excess return $\left(M E R_{i, f, t}\right)$. Both returns are defined as follows:

$$
C R_{i, f, t}=1 \mathrm{n}\left(\frac{M P_{i, f, t}}{A P P_{i, f, t}}\right)
$$

where:

$C R_{i, f, t}=$ the continuous return of stock $i$ of fund $f$ in month $t$;

$M P_{i, f, t}=$ the market price of stock $i$ in month $t$;

$A P P_{i, f, t}=$ the average purchase price of stock $i$ of fund $f$ in month $t$.

and:

$$
M E R_{i, f, t}=1 \mathrm{n}\left(\frac{M P_{i, f, t}}{A P P_{i, f, t}}\right)-1 \mathrm{n}\left(\frac{\text { lbovespa }_{t}}{\text { Ibovespa }_{t-1}}\right)
$$

where:

$M E R_{i, f, t}=$ the market excess return of stock $i$ of fund $f$ in month $t$; Ibovespa $a_{t}=$ the value in points of the Bovespa Index in month $t$.

The difference between both return measures is the point where gains and losses are determined. When CR is used, gains and losses are calculated by prices above or below the average purchase price. When MER is used, the reference point is the market return. In both cases, it is expected that a stock that presents a positive return ( $C R>0$ or MER > 0 ) will have greater probability of being sold. In this sense $\beta_{1}$ is expected to be positive.

Considering that the analyzed sample includes funds that have net asset values (NAV) of different sizes, the natural logarithm of each fund's net asset value was included in both models 1 and 2 as a control variable. The purpose is to observe the relevance of the explanatory variable despite the effect of the fund size.

In order to calculate the return variable all stock prices were adjusted for split and bonus events but they were not adjusted by dividends and interest on equity. According to Odean (1998), dividends may or may not be considered when de- termining the reference point from which gains and losses are calculated. Considering that the inclusion or exclusion of dividends did not affect the results presented by Odean (1998) in the American market, in this study, these adjustments were not performed. Nonetheless not adjusting stock prices by dividends and interest on equity may have introduced some bias when comparing the stock performance and the performance of the Bovespa index since the index is released after adjustments for dividends and interest on equity.

\section{Ordered logit model}

The binary logit model only considers the information about selling (or holding) the stock. Therefore, the information on the value traded is missed. As an enhancement to the previous model, we propose the following ordered logit model, in which the dependent variable will take into account the information about monetary volume involved in each transaction: 


$$
E\left[Y=m \mid X_{i, f, t}\right]=\left[\frac{\exp \left[\tau_{m}-\left(\beta_{0} \operatorname{Return}_{i, f, t}+\beta_{l} 1 \mathrm{n} N A V_{f, t}\right)\right]}{1+\exp \left[\tau_{m}-\left(\beta_{0} \operatorname{Return}_{i, f, t}+\beta_{1} 1 \mathrm{n} N A V_{f, t}\right)\right]}\right]-\left[\frac{\exp \left[\tau_{m-1}-\left(\beta_{0} \operatorname{Re}_{\text {turn }} \operatorname{turft}_{1}+\beta_{l} 1 \mathrm{n} N A V_{f, t}\right)\right]}{1+\exp \left[\tau_{m-1}-\left(\beta_{0} \operatorname{Return}_{i, f, t}+\beta_{1} 1 \mathrm{n} N A V_{f, t}\right)\right]}\right]
$$

The dependent variable $\left(Y_{i, f, t}\right)$ was categorized according to the following criteria:

$$
Y_{i, f, t}=\left\{\begin{array}{l}
0, \text { if } P R S_{i, f, t}=0 \\
1, \text { if } 0.00<P R S_{i, f, t} \leq 0.20 \\
2, \text { if } 0.20<P R S_{i, f, t} \leq 0.40 \\
3, \text { if } 0.40<P R S_{i, f, t} \leq 0.60 \\
4, \text { if } 0.60<P R S_{i, f, t} \leq 0.80 \\
{ }_{5} \text {, if } 0.80<P R S_{i, f, t}
\end{array}\right\},
$$

where the latent variable $P R S_{i, f, t}$ expresses the relative volume of each stock sold over the total volume (sold and not sold):

$$
P R S_{i, f, t}=\frac{R S_{i, f, t}}{R S_{i, f, t}+N R S_{i, f, t}}
$$

where:

$P R S_{i, f, t}=$ the proportion of stock $i$ sold from fund $f$ in month $t$ relative to the overall volume;

$R S_{i, f, t}=$ the monetary volume of stock $i$ sold from fund $f$ in month $t$;

$N R S_{i, f, t}=$ the monetary volume of stock $i$ not sold from fund $f$ in month $t$.

As it can be seen, the observed dependent variable was divided into six categories, the first one groups all cases in which sales were not realized (therefore, $P R S_{i, f, t}=0$ ). The other categories group the positive proportions sold in five intervals of equal extent, reaching the upper limit when $P R S_{i, f, t}=1$, when the whole position of a specific stock is sold in a particular month.

Still in equation (2), Return ${ }_{i, f, t}$ was measured by CR and MER as mentioned before and $\tau_{m}$ is the estimated cutoff point for the category $m$. On the one hand, the objective of the model with $C R$ as independent variable is to check if the stock continuous return, net of the fund size effect, has a positive and statistically significant relationship with the proportion of stocks sold. On the other hand, the objective of the model with MER as independent variable is to check if the stock excess return, net of the fund size effect, presents a positive and statistically significant relationship with the proportion of stocks sold. The use of the stock excess return as an independent variable is justified by the explicit objective of Ibovespa's Active Equity Funds to beat the performance of the market index.

In short, the main purpose of the models described so far is to check if there is a positive association between the return measures and the monetary volume of each stock sold. Therefore, it is expected that the greater the return provided by the stock, the greater will be the proportion of realized sales transactions.

\section{Description of the ordered logistic regression models for testing the bias of mean reversion}

To verify the influence of the bias of mean reversion the following procedures were adopted. First, a criterion was established for determining the gains and losses seen in the transactions carried out by the managers of the analyzed funds. Before describing the procedures for calculating the gains and losses, it has to be pointed out that when the market has appreciated by around $10 \%$ but the stock itself has only appreciated $5 \%$ in the same period, it is likely that an Ibovespa Active Equity Fund manager will consider such an investment as a loss. Similarly, when the market drops by $10 \%$ but the stock only drops by $5 \%$ in the same period it is likely that the manager will consider this investment as a gain.

Therefore, to record gains and losses, index numbers were calculated in order to measure the evolution of the stock price and the evolution of the market index (Ibovespa). Suppose that at the end of month o Fund $A$ has a stock in its portfolio whose average purchase price $(A P P)$ is $\$ 40.00$. This stock was acquired at some point during month 0 , or at various days during the preceding period, but since data on the composition of the fund portfolios refer to the last day of the month, it is not possible to know precisely when this stock was purchased. 
However, it is possible to identify that, on average, the acquisition purchase price of this stock was $\$ 40.00$. Consequently, it is possible to assess the evolution of the price of stock $i$ by comparing $A P P_{i}$ and its $M P_{i}$.

The assumption is that the relationship between $A P P_{i}$ and $M P_{i}$ at the end of month o could reasonably express the evolution of the stock price. So, if $M P_{i}$ is quoted at $\$ 40.80$ at the end of month o an evolution of $2 \%$ has been computed, according to the following formula:

$$
\text { Stock index number }(S I N)=\frac{40.80}{40.00} \times 100=102.00
$$

The same procedure was adopted regarding the market index. The value of Ibovespa at the end of month o and its value at the end of the preceding month were collected in order to check the evolution of the market index. Therefore, if Ibovespa in the preceding month has a value of 10,000 points and at the end of month 0 its value is 10,500 points, an evolution of $5 \%$ is computed, according to the following formula:

$$
\text { Market index number }(M I N)=\frac{10,500}{10,000} \times 100=105.00
$$

Thus the realized and unrealized gains and losses were computed from the index numbers for all stocks. To compute the realized gains and losses based on market excess return (MER), a comparison was made between $S I N$ and $M I N$. For every month in which sales were made by the fund manager, when $S I N>M I N$, a realized gain was recorded and vice-versa. Unrealized gains and losses were recorded in a similar way, but only for months in which no sales were made by the fund manager. So, for every month in which sales were made by the fund manager when $S I N>M I N$, an unrealized gain was recorded. Similarly, for every month in which no sales were made by the fund manager, when $S I N<M I N$, an unrealized loss was recorded.

Once the realized and unrealized gains and losses had been defined the next step was to check the consistency of the stock past performance. This is a vital procedure since it is precisely the stock past performance consistency that will provide the conditions for forming a winning or losing stereotype as predicted by the representativeness heuristic. In other words, a particular stock may exceed market performance in a particular month, but for the manager to be able to classify this stock in the category of winner or loser, it is essential that this positive performance is consistent over a preceding period.

The consequence of this logic is that past performance consistency acts as a fundamental stimulus for the effective re- alization of a gain or loss if the managers' decision process is influenced by the bias of mean reversion. For each stock that resulted in realized or unrealized gains or losses in each of the months analyzed the cumulative excess return for the preceding three months was calculated.

Then the realized and unrealized gains and losses were classified as being consistent or inconsistent. Realized or unrealized gains were consistent for stocks with positive cumulative excess return in the three preceding months and realized or unrealized losses were consistent for stocks with negative accumulated return in excess in the three preceding months. The same procedure was used for the cumulative excess return for the previous six and twelve months.

The following procedures were adopted to check if the mean reversion bias has an influence on realized gains and losses. First, two dummy variables were included in the original ordered model to capture the consistency of the realized gains and losses, based on the preceding stock performance. The first dummy variable, gain consistency dummy (GCD) for all realized and unrealized gains assumes value 1 to identify consistent gains based on the performance of the previous three months, and assumes value o for inconsistent gains and for all realized and unrealized losses. Therefore, the $G C D$ variable is defined as follows:

$$
G D C_{i, f, t}=\left\{\begin{array}{l}
1, \text { if the realized or unrealized gain is consistent } \\
0, \text { for all other cases }
\end{array}\right\}
$$


The second dummy variable, loss consistency dummy $(L C D)$ for all realized and unrealized losses assumes value 1 to identify consistent losses based on the performance of the previous three months and assumes value o for inconsistent losses and for all realized and unrealized gains. Therefore, the $L C D$ is defined as follows:

$$
L C D_{i, f, t}=\left\{\begin{array}{l}
1, \text { if the realized or unrealized loss is consistent } \\
0, \text { for all other cases }
\end{array}\right\}
$$

The same procedure was carried out for the preceding six and twelve months, based on the cumulative excess return. Therefore, these dummy variables were included in the ordered logistic regression model in order to capture the consistency in gains and losses based on the preceding period.

With this model, the purpose is to check if the consistency of stock past performance, despite the effect of the fund size, presents any relationship with the proportion of stocks sold. On the one hand, the bigger the consistency of the gain the greater will be the probability to sell the stock. On the other hand, the bigger the consistency of the loss the greater will be the probability to hold the stock. In short, it is expected a positive relationship between $G C D$ and the dependent variable as well as a negative relationship between $L C D$ and the dependent variable.

\section{RESULTS}

\section{Results from binary logit model}

In Table 1, we present the results of the binary logit regression models for the full sample. The table presents the estimated coefficients for each independent and control variable and the standard error associated with each of them, as well as the likelihood ratio. The results for Model 1 show that $C R_{i, f, t}$ coefficient has a positive and statistically significant value at $1 \%$ level. In Model 2, the results also reveal the same interpretation for the variable $M E R_{i, f, t}$. The size of the fund has a positive and statistically significant coefficient for both models. The likelihood ratio indicates that all regressors jointly have a statistically significant impact on the dependent variable at $1 \%$ level.

The results of estimated coefficients for both return measures $\left(C R_{i, f, t}\right.$ and $\left.M E R_{i, f, t}\right)$ in Models 1 and 2 indicates that, in general, the bigger the stock return the greater will be the probability of selling the stock. This results show a pattern of behavior that is consistent with the loss aversion phenomenon predicted by the prospect theory approach indicating that equity fund managers sell winning stocks more quickly than losing stocks.

\section{TABLE 1. Binary logit models}

\begin{tabular}{|c|c|c|c|c|}
\hline \multirow{2}{*}{$\begin{array}{l}\text { Independent } \\
\text { variable }\end{array}$} & \multicolumn{2}{|c|}{ Model 1} & \multicolumn{2}{|c|}{ Model 2} \\
\hline & Coefficient & Std. error & Coefficient & Std. error \\
\hline $\mathrm{CR}_{i, f, t}$ & $0.5256^{*}$ & 0.0378 & & \\
\hline $\mathrm{MER}_{i, f, t}$ & & & $0.4609^{*}$ & 0.0400 \\
\hline $\ln \mathrm{NAV}_{f, t}$ & $0.0411^{*}$ & 0.0058 & $0.0415^{\star}$ & 0.0058 \\
\hline Intercept & $-1.1667^{\star}$ & 0.1005 & $-1.1380^{*}$ & 0.1004 \\
\hline $\begin{array}{l}\text { Likelihood } \\
\text { Ratio }\end{array}$ & \multicolumn{2}{|c|}{$252.6107^{\star}$} & \multicolumn{2}{|c|}{$189.7605^{*}$} \\
\hline
\end{tabular}

Total number of observations: 45,668

Note: The dependent variable is 1 when stocks were sold and zero otherwise.

The independent variables are the stock continuous return (CR) and stock

market excess return (MER), and the natural logarithm of the net asset value

of the fund (NAV). The symbols * ${ }^{* *}$ e $\dagger$ denote the statistical significance of

the coefficient at $1 \%, 5 \%$ and $10 \%$ levels, respectively. The estimated residuals

were calculated in a robust manner according to the Huber/White procedure.

\section{Results from ordered logit model}

In Table 2 the results of the ordered logistic regression model for the full sample are presented. The table has similar structure as Table 1, with the inclusion of the estimated cutoff points of the ordered logit regression. The results for Model 3 show that $C R_{i f t}$ coefficient is positive and statistically significant at $1 \%$ level. In this case, the positive sign indicates that, in general, the bigger the stock continuous return the greater will be the proportion of stocks sold, indicating the existence of the disposition effect. In Model 4 , the results also reveal a positive and statistically significant coefficient at $1 \%$ level for the variable $M E R_{i, f, t}$ which indicates that, in general, the greater the stock excess return, the greater will be the proportion of stocks sold.

As mentioned previously the main purpose of estimating Models 3 and 4 is to take into account the information about monetary volume involved in each transaction. Thus, the results of estimated coefficients for both return measures $\left(C R_{i, f, t}\right.$ and $\left.M E R_{i, f, t}\right)$ indicates that when a stock presents a positive return equity fund managers tend to sell a great proportion of this stock. This result corroborates again the idea that the loss aversion predicted by prospect theory seems to guide de decision-making process of equity fund managers. 
TABLE 2. Ordered logit models

\begin{tabular}{|c|c|c|c|c|}
\hline \multirow{2}{*}{$\begin{array}{l}\text { Independent } \\
\text { variable }\end{array}$} & \multicolumn{2}{|c|}{ Model 3} & \multicolumn{2}{|c|}{ Model 4} \\
\hline & Coefficient & $\begin{array}{l}\text { Std. } \\
\text { error }\end{array}$ & Coefficient & Std. error \\
\hline $\mathrm{CR}_{i, f, t}$ & $0.2926^{\star}$ & 0.0343 & & \\
\hline $\operatorname{MER}_{i, f, t}$ & & & $0.1745^{*}$ & 0.0365 \\
\hline $\operatorname{lnNAV}_{f, t}$ & $0.0374^{*}$ & 0.0057 & $0.0378^{*}$ & 0.0057 \\
\hline $\mathrm{\tau}_{1}$ & $1.0872^{*}$ & 0.0981 & $1.0723^{\star}$ & 0.0981 \\
\hline$\tau_{2}$ & $2.0433^{*}$ & 0.0987 & $2.0273^{*}$ & 0.0986 \\
\hline$\tau_{3}$ & $2.5312^{*}$ & 0.0991 & $2.5153^{*}$ & 0.0990 \\
\hline$\tau_{4}$ & $2.8854^{*}$ & 0.0995 & $2.8696^{\star}$ & 0.0994 \\
\hline$\tau_{5}$ & $3.1654^{*}$ & 0.1001 & $3.1497^{\star}$ & 0.1000 \\
\hline $\begin{array}{l}\text { Likelihood } \\
\text { Ratio }\end{array}$ & \multicolumn{2}{|c|}{$113.8497^{\star}$} & \multicolumn{2}{|c|}{$67.1709^{*}$} \\
\hline
\end{tabular}

Total number of observations: 45,668

Note: The dependent variable used in the estimation was based on the latent variable $(P R S$, ). The independent variables used are the stock continuous return $(C R)$, the stock market excess return $(M E R)$ and the natural logarithm of the net asset value of the fund ( $\ln N A V)$. The symbols *, ** e + denote the statistical significance of the coefficient at $1 \%, 5 \%$ and $10 \%$ levels, respectively.

The estimated residuals were calculated in a robust manner according to the Huber/White procedure.

In Models 1 to 4, the purpose was to verify if equity fund managers present the first behavioral argument for the disposition effect as proposed by Odean (1998), i.e., that they have a value function as the prospect theory claims. Therefore, the main point of these models was to analyze the relationship between the effective selling of stocks (either in binary and categorized variables) and the stock returns in the period.

The second behavioral argument states that investors incorrectly expect that there will be a mean reversion in the stock returns. To verify the mean reversion hypothesis, we estimated Models 5 to 7 presented in Table 3 that include dummy variables for gains and losses consistency, GCD and LCD, respectively.

Model 5 presents the results with dummy variables for consistency based on the performance over the three preceding months. As it can be seen, GCD coefficient is positive and statistically significant at $1 \%$ level whereas $L C D$ did not show statistical significance. Model 6 shows the results with dummy variables for consistency based on the performance of the six preceding months. The same pattern that was seen in the threemonth model can also be seen in the six-month period as well. GCD coefficient is positive and statistically significant sign at $1 \%$ level whereas $L C D$ coefficient is not significant. A surprising aspect in this model is that with the coefficient of $M E R$, it is not significant. Finally, the results reported in Model 7 with dummy variables for consistency based on performance over the preceding twelve months follow the same pattern as the previous models. GCD coefficient is positive and statically significant whereas $L C D$ is not significant. The only difference in this case is that $G C D$ is significant at $5 \%$ level.

\section{TABLE 3. Ordered logit models with mean-reversion variables}

\begin{tabular}{|c|c|c|c|c|c|c|}
\hline \multirow{2}{*}{$\begin{array}{l}\text { Independent } \\
\text { variable }\end{array}$} & \multicolumn{2}{|c|}{ Model 5} & \multicolumn{2}{|c|}{ Model 6} & \multicolumn{2}{|c|}{ Model 7} \\
\hline & Coefficient & Std. error & Coefficient & Std. error & Coefficient & Std. error \\
\hline $\mathrm{MER}_{i, f, t}$ & $0.1030 \star \star$ & 0.0465 & 0.0730 & 0.0477 & $0.1387^{\star}$ & 0.0486 \\
\hline $\mathrm{GDC}_{i, f, t}$ & $0.0859^{*}$ & 0.0229 & $0.1176^{\star}$ & 0.0235 & $0.0577^{\star *}$ & 0.0239 \\
\hline $\operatorname{LDC}_{i, f, t}$ & 0.0171 & 0.0259 & 0.0227 & 0.0261 & 0.0230 & 0.0269 \\
\hline $\ln \mathrm{NAV}_{f, t}$ & $0.0382 *$ & 0.0057 & $0.0393^{*}$ & 0.0057 & 0.0402 * & 0.0058 \\
\hline $\mathrm{\tau}_{1}$ & $1.1095^{\star}$ & 0.0989 & $1.1399^{\star}$ & 0.0997 & $1.1321^{*}$ & 0.1013 \\
\hline$\tau_{2}$ & $2.0649^{\star}$ & 0.0994 & $2.0984^{\star}$ & 0.1003 & $2.0982 *$ & 0.1018 \\
\hline$\tau_{3}$ & $2.5530^{*}$ & 0.0997 & $2.5894^{\star}$ & 0.1006 & $2.5892^{*}$ & 0.1022 \\
\hline $\mathrm{\tau}_{4}$ & $2.9073^{*}$ & 0.1002 & $2.9463^{*}$ & 0.1011 & $2.9517^{*}$ & 0.1027 \\
\hline$\tau_{5}$ & $3.1874^{*}$ & 0.1007 & $3.2298^{\star}$ & 0.1017 & $3.2403^{*}$ & 0.1033 \\
\hline Likelihood Ratio & \multicolumn{2}{|c|}{$80.4838^{\star}$} & \multicolumn{2}{|c|}{$93.2341^{*}$} & \multicolumn{2}{|c|}{$76.8127^{\star}$} \\
\hline
\end{tabular}

Total number of observations: 45,668

Note: The dependent variable used in the estimation was based on the latent variable (PRS.). The independent variable is the stock market excess return (MER), the dummy variable for consistency of gain (GCD), the dummy variable for consistency of loss ( $L C D$ ) and the natural logarithm of the net asset value of the fund (InNAV). The symbols *, ** $\mathrm{e}+$ denote the statistical significance of the coefficient at $1 \%, 5 \%$ and $10 \%$ levels, respectively. The estimated residuals were calculated in a robust manner according to the Huber/White procedure. 
Considering the positive and statistically significant sign of the estimated coefficients for the $G C D$ variable in the three different periods reported, results indicate that more consistent gains based on past performance induce managers to sell increasing proportions of the stock. Consistent losses based on $L C D$ coefficients did not show the expected sign or statistical significance.

In summary, the overall results of mean reversion hypothesis showed a certain asymmetry and ambiguity. On the one hand, consistent gains with a stock are associated with increasing sales transactions with this stock. On the other hand, consistent losses also produced the same effect although without statistical significance. Thus, these results could not corroborate consistently the hypothesis that the disposition effect arises from mean reversion bias.

\section{CONCLUSION}

The central purpose of this paper was to investigate if Brazilian equity fund managers exhibit the disposition effect. To do so, the purchase and sale transactions of a sample of 51 investment funds were analyzed from July 2002 to June 2008 . This main purpose led to a secondary one which consisted in testing two competing behavioral motivations for explaining the disposition effect: prospect theory and mean reversion bias.

To achieve the proposed goals two independent variables were defined to set two points of reference in order to determine capital gains and losses. The first one was defined as the stock continuous return based on the relationship between the market price of the stock and its average purchase price. The second consisted in the stock market excess return based on the difference between the stock continuous return and the continuous market index return. The natural logarithm of the net asset value of the fund was also used as a control variable for size effect. Based on the independent variables, logit regression models were estimated to check the relationship between the return variables and the proportion of stocks sold.

In summary, when the stock continuous return $(C R)$ was used as an independent variable the estimated coefficients presented evidence that equity fund managers exhibit the disposition effect. Such coefficients showed a positive and statistically significant relationship with the proportion of stocks sold. The same results were produced when the market excess return $(M E R)$ was used as the independent variable.

After testing if prospect theory permeates the decision-making process of fund managers, the results of the mean reversion hypothesis were discussed. In this case, a few proce- dures were adopted to determine the consistency of gains and losses based on past performance. In order to do so, dummy variables were included to capture the consistency of gains and losses. The estimated coefficients for gain consistency (GCD) were positive and statistically significant. However, the estimated coefficients for loss consistency ( $L C D$ ) did not show the expected sign or statistical significance.

In this sense, the main conclusions reached in this study are: (1) the prospect theory seems to drive the decision-making process of funds managers in this analyzed sample considering the results of both binary and ordered logit regression models in which the stock continuous return and the stock market excess return were used as independent variables; (2) the hypothesis that the disposition effect arises from the mean reversion bias cannot be corroborated by the results of the estimated coefficients for the dummy variables of consistency based on past performance.

\section{REFERENCES}

Arruda, P. B. (2006). Uma investigação sobre o efeito disposição. 2006. 81 p. Masters dissertation in Production Engineering, Universidade Federal de Santa Catarina, Florianópolis.

Barber, B. M.; Lee, Y. T.; Liu, Y. J.; Odean, T. (2007). Is the aggregate investor reluctant to realise losses? Evidence from Taiwan. European Financial Management, 13(3), 423-447.

Barberis, N. \& Xiong, W. (2012). Realization utility. Journal of Financial Economics, 104(2), 251-271.

Ben-David, I. \& Hirshleifer, D. (2012). Are investors really reluctant to realize their losses? Trading responses to past returns and the disposition effect. Review of Financial Studies, 25(8), 2485-2532.

Boebel, R. B. \& Taylor, L. (2000). The disposition effect: do New Zealand investors keep their mistakes? Retrieved on 9 December 2008 from http:// www.business.otago.ac.nz/FINC/research/pdf/o1/NZLossesold.pdf.

Brasil. (2004). Instrução $n^{\circ}$ 409, de 18.08.2004. Diário Oficial da República Federativa do Brasil, Comissão de Valores Mobiliários, Brasília, DF, 24.08.2004. Retrieved on 9 December 2008 from http:// www.cvm.gov.br.

Brasil. (1999). Instrução nº 302, de 05.05.1999. Diário Oficial da República Federativa do Brasil, Comissão de Valores Mobiliários, Brasília, DF, 10.05.1999. Retrieved on 9 December 2008 from http://www.cvm.gov.br.

Brown, P.; Chappel, N.; Silva Rosa, R.; Walter, T. (2006). The reach of the disposition effect: large sample evidence across investor classes. International Review of Finance, 6(1-2), 43-78.

Chan, W. S., FrankeL, R., \& Kothari, S. P. (2004). Testing behavioral finance theories using trends and consistency in financial performance. Journal of Accounting and Economics, 38(December), 3-50.

Dhar, R. \& Zhu, N. (2002). Up close and personal: an individual level analysis of the disposition effect. SSRN eLibrary. Retrieved on 9 December 2008 from http://ssrn.com/paper=302245. 
Frazzini, A. (2006). The disposition effect and underreaction to news. The Journal of Finance, 61(4), 2017-2046.

Grinblatt, M. \& Keloharju, M. (2000). The investment behavior and performance of various investor types: a study of Finland's unique data set. Journal of Financial Economics, 55(1), 43-67.

Harris, L. (1988). Predicting contemporary volume with historic volume at differential price levels: evidence supporting the disposition effect: discussion. The Journal of Finance, 43(3), 698-699.

Kahneman, D. \& Tversky, A. (1972). Subjective probability: a judgment of representativeness. Cognitive Psychology, 3(3), 430-454.

Kahneman, D. \& Tversky, A. (1973). On the psychology of prediction. Psychological Review, 80(4), 237-251.

Kahneman, D. \& Tversky, A. (1979). Prospect theory: an analysis of decision under risk. Econometrica, 47(2), 263-292.

Karsten, J. G. (2005). O efeito disposição: um estudo empírico no Brasil. 2005, 73 p. Masters dissertation in Economics, Escola de Administração de Empresas de São Paulo, Fundação Getulio Vargas, São Paulo.

Lakonishok, J. \& Smidt, S. (1986). Volume for winners and losers: taxation and other motives for stock trading. The Journal of Finance, 41(4), 951-974.

Li, Y. \& Yang, L. (2013). Prospect theory, the disposition effect, and asset prices. Journal of Financial Economics, 107(3), 715-739.

Locke, P. R. \& Mann, S. C. (2000). Do professional traders exhibit loss realization aversion. SSRN eLibrary, 2000. Retrieved on 9 December 2008 from http://ssrn.com/paper=251942.

Macedo Jr., J. S. (2003). Teoria do prospecto: uma investigação utilizando simulação de investimentos. 2003. 203p. Doctoral thesis in Production Engineering, Universidade Federal de Santa Catarina, Florianópolis.

Mineto, C. A. L. (2005). Percepção ao risco e efeito disposição: uma análise experimental da teoria dos prospectos. 2005. 154p. Doctoral thesis in Production Engineering, Universidade Federal de Santa Catarina, Florianópolis.
Odean, T. (1998). Are investors reluctant to realize their losses? The Journal of Finance, 53(5), 1775-1798.

Ranguelova, E. (2001). Disposition effect and firm size: new evidence on individual investor trading activity. SSRN eLibrary, 2001. Retrieved on 9 December 2008 from http://ssrn.com/paper=293618.

Shapira, Z. \& Venezia, I. (2001). Patterns of behavior of professionally managed and independent investors. Journal of Banking and Finance, 25(8), 1573-1587.

Shefrin, H. (2002). Beyond greed and fear: understanding behavioral finance and psychology of investing. New York: Oxford University Press. 368 p.

Shefrin, H. (2005). A behavioral approach to asset pricing. Amsterdam: Elsevier Academic Press. 488 p.

Shefrin, H. \& Statman, M. (1985). The disposition to sell winners too early and ride losers too long: theory and evidence. The Journal of Finance, 40(3), 777-790.

Thaler, R. H. (1985). Mental accounting and consumer choice. Marketing Science, 4(3), 199-214.

Thaler, R. H; Shefrin, H. (1981). An economic theory of self-control. Journal of Political Economy, 89(2), 392-410.

Tizziani, E. (2008). O efeito disposição na indústria brasileira de fundos de investimento em ações: um estudo em finanças comportamentais. 2008. 78 p. Masters dissertation in Business Administration, Pontifícia Universidade Católica do Rio de Janeiro, Rio de Janeiro.

Tversky, A. \& Kahneman, D. (1973). Availability: a heuristic for judging frequency and probability. Cognitive Psychology, 5(2), 207-232.

Tversky, A. \& Kahneman, D. (1974). Judgment under uncertainty: heuristics and biases. Science, 185(4157), 1124-1131.

Tversky, A. \& Kahneman, D. (1986). Rational choice and the framing of decisions. The Journal of Business, 59(4), 251-278.

Weber, M. \& Camerer, C. F. (1998). The disposition effect in securities trading: an experimental analysis. Journal of Economic Behavior and Organization, 33(2), 167-184. 